\title{
On safe ground? Analysis of European urban geohazards \\ using satellite radar interferometry
}

\author{
Renalt Capes, Richard Teeuw \\ University of Portsmouth, School of Earth \& Environmental Sciences, Burnaby Building, Portsmouth, PO1
} 2UP, UK.

Corresponding author email: renalt.capes@port.ac.uk

\begin{abstract}
Urban geological hazards involving ground instability can be costly, dangerous, and affect many people, yet there is little information about the extent or distribution of geohazards within Europe's urban areas. A reason for this is the impracticality of measuring ground instability associated with the many geohazard processes that are often hidden beneath buildings and are imperceptible to conventional geological survey detection techniques. Satellite radar interferometry, or InSAR, offers a remote sensing technique to map mm-scale ground deformation over wide areas given an archive of suitable multi-temporal data. The EC FP7 Space project named PanGeo (2011-2014), used InSAR to map areas of unstable ground in 52 of Europe's cities, representing $\sim 15 \%$ of the EU population. In partnership with Europe's national geological surveys, the PanGeo project developed a standardised geohazard-mapping methodology and recorded 1286 instances of 19 types of geohazard covering $18,000 \mathrm{~km}^{2}$. Presented here is an analysis of the results of the PanGeo-project output data, which provides insights into the distribution of European urban geohazards, their frequency and probability of occurrence. Merging PanGeo data with Eurostat's GeoStat data provides a systematic estimate of population exposures. Satellite radar interferometry is shown to be as a valuable tool for the systematic detection and mapping of urban geohazard phenomena.
\end{abstract}

Keywords: Urban geohazards, Satellite radar interferometry (InSAR), PanGeo, Europe.

\section{1: INTRODUCTION}

This article presents an analysis of results from the EC FP7 Space project named PanGeo (www.pangeoproject.eu) that ran from 2011 to 2014. Based upon the satellite remote sensing technique of radar interferometry, the project mapped 19 types of geological hazard within 52 European cities. Geological hazards, or 'geohazards', are conditions relating to geology that have the potential to cause harm or damage (UNISDR, 2016), often involving some form of ground 
motion or instability. Geohazards can be costly, dangerous, and affect many people. This is especially true in urban environments which greatly increase the impacts of geohazards and amplify their effects (Howard, 1999). Geohazards include fast-moving events, such as landslides, earthquakes or collapses associated with mining that often result in metre-scale ground movements occurring over a few minutes. Geohazards also include slower-moving (mm/year to $\mathrm{cm} /$ year) phenomena, that often remain hidden and undetected beneath the built environment, but that still present significant costs to society, e.g. the €11bn of losses in the UK between 1971 and 2009 for damage caused by shrink-swell clays (MunichRe, 2016). Ground instability may lead to financial loss with regard to ownership or management of property, impacting on householders, businesses developers or local government (Booth, Diaz Doce, Harrison, \& Wildman, 2010). With 70\% of the global population likely to live in urban areas by 2045 (Ministry of Defence, 2014), the vulnerability of society to urban geohazards is set to grow with increasing population density and collocation of high-value assets (European Environment Agency, 2010).

Although urban geohazards pose a significant threat to the European economy, information is scarce regarding the extent and distribution of geohazards within European urban areas. The ability to measure vulnerability and exposure, as a part of disaster risk reduction activities, was a priority in the Hyogo Framework for Action (2007), yet still no universal measurement methodology exists and there are few relevant quantitative data sets (Kaluarachchi, Indirli, Ranguelov, \& Romagnoli, 2014). Even for landslides, ubiquitous and deadly in parts of Europe, there is no European overview or policy, there are discrepancies in databases, and information is not generally available (EEA: European Environment Agency, 2010). Indeed, that EEA reference only cites 77 landslides in Europe (although not specifying any size threshold), whereas the research presented here has recorded 292 landslides within just the 52 cities examined. National geological surveys maintain geospatial databases of geohazards, but these vary considerably in terms of convention, coverage and quality from one survey to another and cannot represent a systematic or accessible European geohazard inventory.

A reason for the lack of knowledge relating to the distribution of urban geohazards has been the impracticality of mapping the evidence for ground instability, or ground motions, over wide areas at an effective scale. This means that most inventories are ones of geohazard 'susceptibility' deduced from interpretations of geological maps which may vary considerably in scale, for instance, from 1:10,000 to 1:200,000. Inventories may also include data gathered in the field, but 
such observations are of necessity smaller-scale. Europe's cities have been built over centuries, layer on layer, and in many cases the underlying surficial geology has been obliterated or is unknown. An indicator of some urban ground instabilities would be insurance claims history, but on a European scale such data are incomplete, disaggregated, often non-standardised and/or subject to commercial confidentiality.

\section{1: Satellite radar interferometry (InSAR)}

The application of InSAR for detecting and measuring Earth-surface motions has revolutionised the capability to map geohazards (Gabriel, Goldstein, \& Zebker, 1989; Massonnet et al., 1993). InSAR compares the phase of the radar echo on a pixel-by-pixel basis throughout a multi-temporal synthetic aperture radar (SAR) dataset to calculate changes in the line-of-sight distance between the satellite and the Earth's surface. In other words InSAR is able to map terrain motion. The simplest form of InSAR (commonly known as 'conventional') uses three SAR scenes of the same area separated in time to build two digital elevation models (DEM) that are differenced to reveal topographic change that might have occurred between the imaging dates (Gabriel et al., 1989). Two SAR scenes and a conventionally-derived DEM can also be used. The key limitation of conventional InSAR is atmospheric refraction influencing signal path length, in effect reducing displacement resolution to around a $\mathrm{cm}$ - too coarse to measure many slower-moving ground instabilities (although often suitable for measuring the larger, nearly-instantaneous, displacements relating to co-seismic events). The PanGeo project employed the more advanced and sensitive technique known as 'Persistent Scatterer' InSAR (PSI) that uses many tens of multi-temporal SAR datasets to facilitate a more accurate modelling of the atmospheric contribution, thereby increasing displacement resolution to sub-millimetre precision. PSI processing outputs a timeseries for each radar-scatterer that is usually converted into a 2D map of average annual velocities covering the epoch represented by the dataset (Ferretti, Prati, \& Rocca, 2001; Crosetto, Monserrat, Cuevas-González, Devanthéry, \& Crippa, 2015; Capes, R. Marsh, 2009)

The objective of PanGeo was to productise PSI within a geohazard information system aimed at the non-specialist, particularly local authorities who currently have little, if any, information on geohazards in their areas of responsibility. The project incorporated the InSAR technique into the mapping of unstable ground in 52 European cities, representing 15\% of the total EU population and nearly a third (29\%) of the EU27 built environment (European Commission, 2016a). In partnership with all 27 of Europe's national geological surveys the project developed a 
standardised geohazard-mapping methodology (Table 1), and went on to record 1286 instances of 19 types of geohazard covering $18,000 \mathrm{~km}^{2}$.

Table 1: Geohazard Groups and Types as agreed between 27 national geological surveys for the PanGeo project. All involve ground movements.

\section{1: Deep Seated Motions}

1.1: Earthquake (seismic hazard); 1.2. Tectonic movement;

1.3: Salt tectonics; 1.4: Volcanic inflation/deflation.

\section{Natural Ground Instability}

2.1. Landslide; 2.2. Soil Creep; 2.3. Ground Dissolution;

2.4. Collapsible Ground.

\section{Natural Ground Movement}

3.1. Compressible Ground; 3.2. Shrink-Swell Clays.

\section{Man Made Ground Instability}

4.1. Shallow Compaction; 4.2. Peat Oxidation Ground;

4.3. Groundwater Abstraction; 4.4. Mining; 4.5. Underground

Construction; 4.6. Made Ground; 4.7. Oil and Gas Production

\section{Other 6. Unknown}

Presented here is an analysis of the results of further processing of the PanGeo-project output data to provide a first understanding of the distribution of geohazards across these 52 European urban areas, along with their frequency and probability of occurrence. Cross-referencing the PanGeo results with Eurostat's GeoStat data has produced the first systematic estimates of population exposures to urban geohazards across Europe.

\section{2: METHOD}

The PanGeo project utilised InSAR as the basis for the development of a standardised geospatial inventory of urban geohazards. The inventory covered 52 of Europe's largest cities, all with populations $>100,000$ (Table 2 and Figure 1). Each country has two cities included, except Cyprus and Luxembourg, as these countries have only one city each with a population exceeding 100,000. 
Table 2: The 52 European cities for which geohazards were mapped.

\begin{tabular}{|l|l|l|}
\hline Austria & Salzburg & Vienna \\
\hline Belgium & Brussels & Liege \\
\hline Cyprus & Lefkosia & \\
\hline Czech Republic & Prague & Ostrava \\
\hline Denmark & Copenhagen & Aalborg \\
\hline Estonia & Tallinn & Tartu \\
\hline Finland & Helsinki & Turku \\
\hline France & Lyon & Toulouse \\
\hline Germany & Berlin & Hannover \\
\hline Greece & Athens & Larissa \\
\hline Hungary & Budapest & Miskolc \\
\hline Ireland & Cork & Dublin \\
\hline Italy & Palermo & Rome \\
\hline Latvia & Riga & Liepaj \\
\hline Lithuania & Kaunas & Vilnius \\
\hline Luxembourg & Luxembourg & \\
\hline Malta & Gozo & Valetta \\
\hline Netherlands & Amsterdam & Rotterdam \\
\hline Poland & Nowy Sacz & Warsaw \\
\hline Portugal & Faro & Lisbon \\
\hline Romania & Bucarest & Cluj-Napoca \\
\hline Slovakia & Kosice & Presov \\
\hline Slovenia & Ljubljana & Maribor \\
\hline Spain & Murcia & Zaragoza \\
\hline Sweden & Goteborg & Stockholm \\
\hline UK & London & Stoke on Trent \\
\hline
\end{tabular}




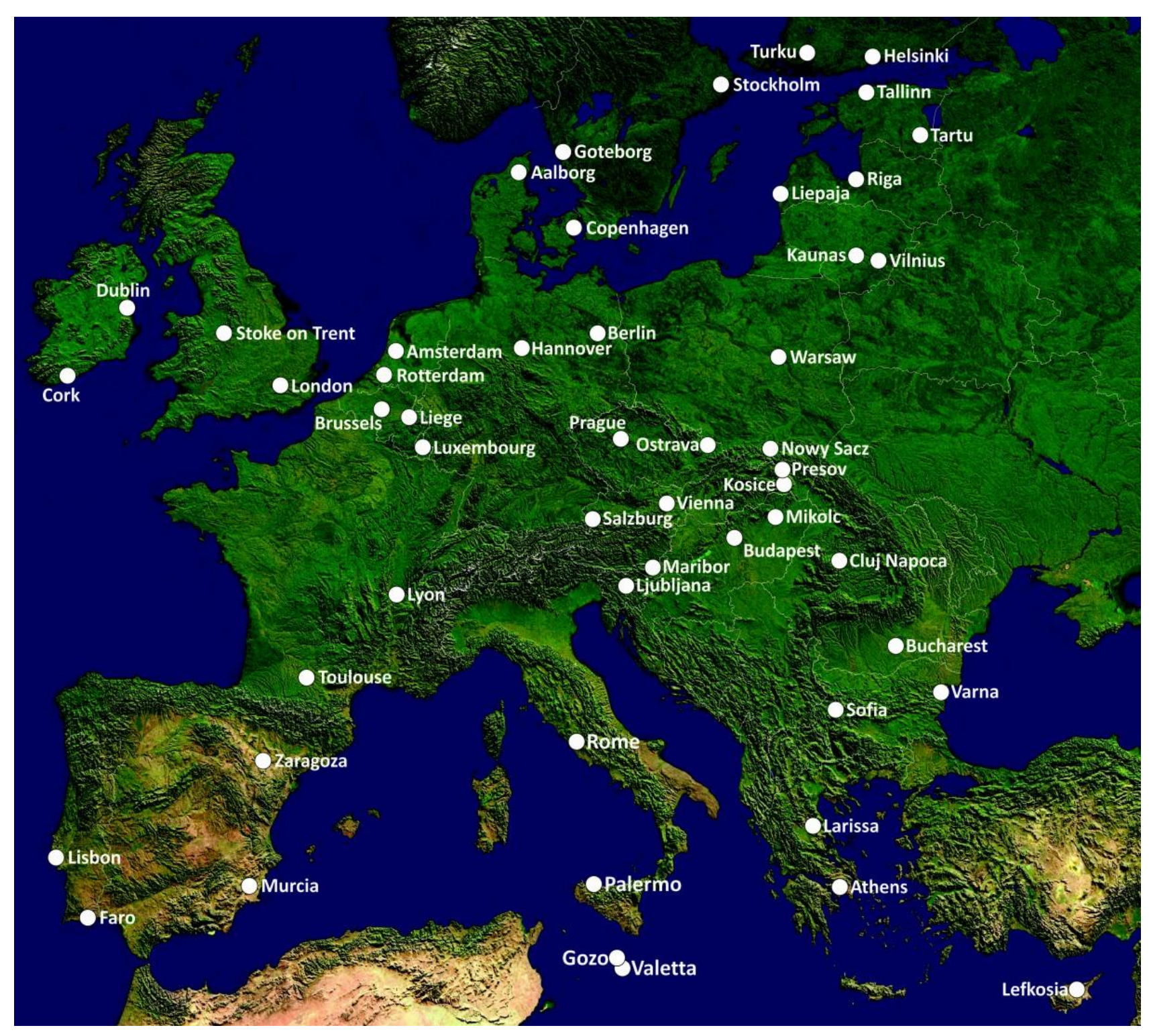

Figure 1: Location map for the 52 cities included in the PanGeo project and this study (base map source: ESA 2012)

Besides requiring a population of $>100,000$, the cities were selected in two ways: $27 / 52$ were preselected on the basis of having already been PSI processed in the ESA project Terrafirma (www.terrafirma.eu.com): the use of Terrafirma output, plus the saving of the corresponding PSI processing costs was expedient to winning the EC PanGeo contract. 19 Terrafirma cities used in PanGeo were chosen to maximise population exposure, e.g. first or second largest cities, while 8 were chosen because of known or suspected ground instabilities, e.g. Palermo and Toulouse. The remaining 25/52 cities were nominated by each country's geological survey as part of the PanGeo project, 22 on the basis of population, and 3 due to geohazard drivers (Aalborg, Nowy Sacz and Faro). In summary, 11 (21\%) of the 52 cities included in PanGeo were chosen due to known or suspected geohazards, thereby introducing the probability of bias in the analyses, although the 
mix of geohazards in these 11 cities varied widely and were common throughout the datasets, thereby minimising possible bias. A normal distribution of geohazards across all large European cities would imply some similarity of geology, topography, climate and environmental factors across the continent, where the increased levels of certain geohazard-types, such as earthquakes, subsidence due to water-abstraction and landslides towards the south and west of Europe indicates otherwise (McCann, 2008). Last, most large European cities evolved from smaller settlements originally built near rivers or coastlines, inherently increasing the risks of subsidence due to compressible and made ground. In conclusion, the 52 cities included in the study do not represent a random sample of European cities with populations $>100,000$, and some care is therefore needed in the interpretation of the results.

The PSI processing for both the Terrafirma and PanGeo InSAR data was undertaken by the four acknowledged, operational providers of the time; TeleRilevamento Europa (IT), Gamma Remote Sensing (CH), Altamira Information (ES), and NPA Satellite Mapping (UK). All four had passed through a stringent, ESA-funded, validation exercise in the Terrafirma project that certified the consistency of their PSI processing, and standardised their output (M Crosetto et al., 2008). All 52 cities were PSI-processed using all ESA SAR mission data available for each city at the time. This involved C-band $(5.6 \mathrm{~cm} \lambda$ ) SAR data from ERS-1/2 and Envisat, ranging from 1992 to 2010. PSI processing epochs varied from city to city depending on SAR data availability. This implies the relative time-independence of many geohazard types, e.g. clay shrink-swell cycles and tectonic processes, but geohazard phenomena can have distinct life-cycles such as compaction of made land or the effects of long-wall coal-mining. The analysis should therefore be considered as a 'long-exposure snapshot' of ground instabilities across these cities.

The PanGeo project gave training to the geological surveys in the understanding and use of PSI data before providing the InSAR data for their analysis and interpretation. Using these data, along with other maps, field data, and existing knowledge, each survey mapped polygons of urban geohazard at 1:10,000 scale, classifying them using 19 geohazard types. Areas of geohazard were determined in one or more of three ways: i) by evidence of ground motion from the InSAR results, ii) from fieldwork and geological survey observations, and iii) interpretation of geological maps to indicate susceptibility to a geohazard, i.e. the 'geological potential' for a geohazard. Thus, for each of the 52 cities, a 'Ground Stability Layer' GIS shapefile file was created containing all the geohazard polygons for that city, along with an associated database providing: hazard type, 
determination method, confidence level and areal extent. A 'Geohazard Description' document was also compiled by the relevant national geological survey, where an overall geological context was provided, along with a systematic interpretation of each geohazard polygon that made up the Ground Stability Layer for that city. The resulting data can be accessed in Google Earth via the PanGeo website, where geohazard polygons can be viewed draped over each city. Clicking on a polygon produces a pop-up table showing its corresponding database fields, with a further click displaying the polygon's full interpretation. Examples for Rome are shown in Figures 2 and 3.

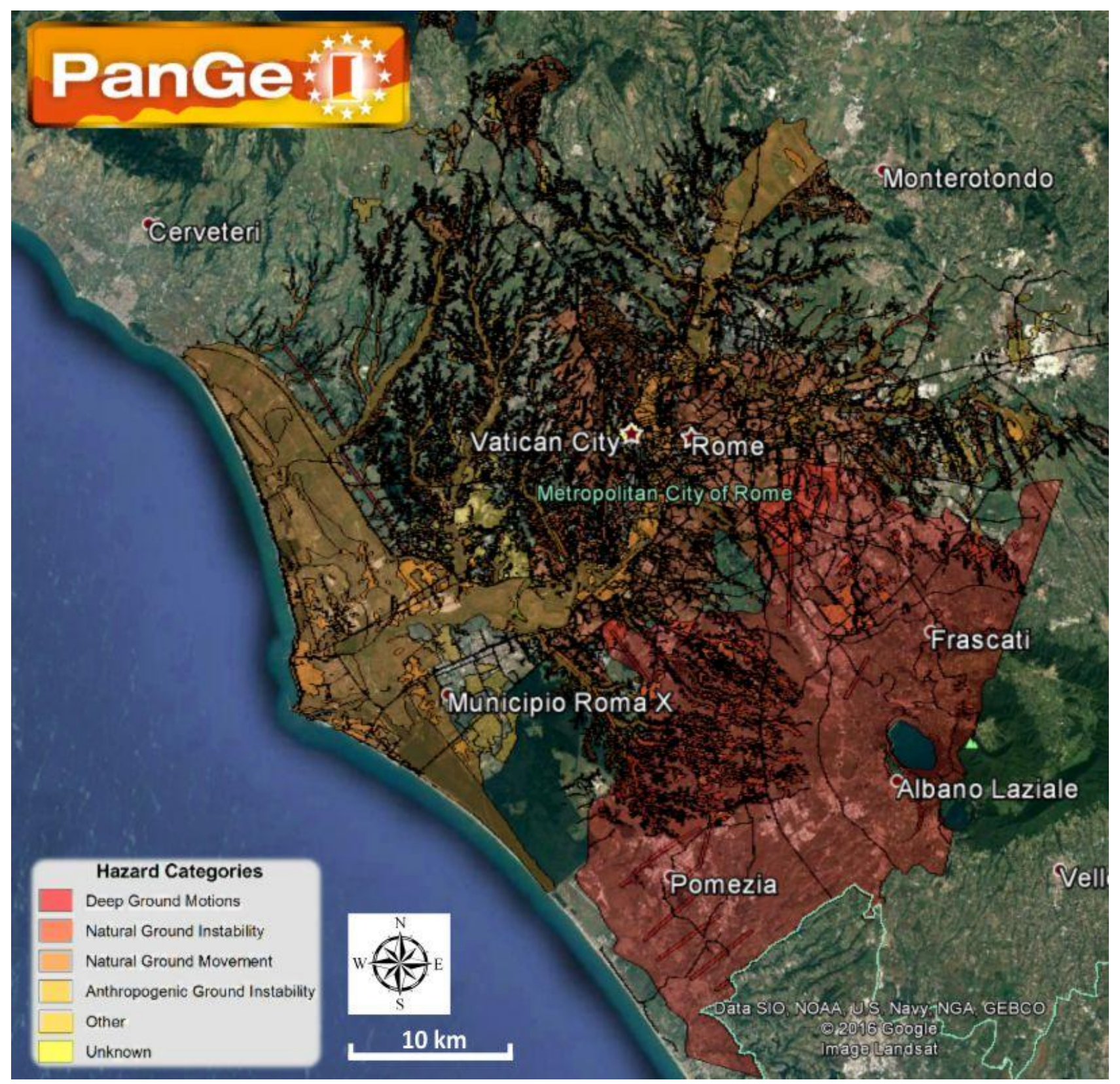

Figure 2: PanGeo 'Ground Stability Layer' for Rome superimposed over optical data in Google Earth. The different colour polygons depict one of 19 geohazard-types as further detailed in Figure 3. Polygons of differing geohazard-type can overlap, and some are obscured. 


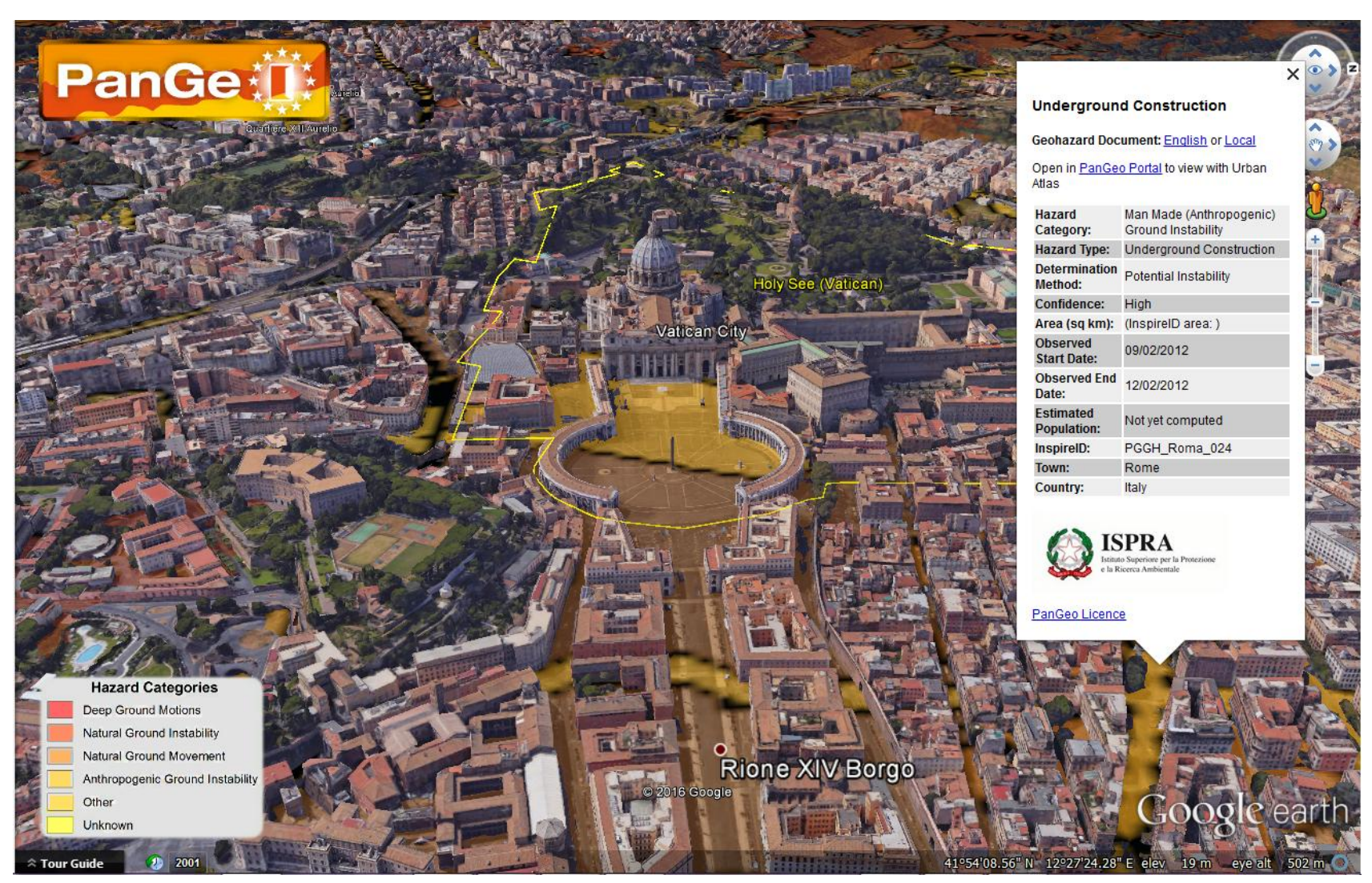

Figure 3: Rome Ground Stability Layer draped over a Google-Earth 3D map. The pop-up on the right summarises that particular polygon's database fields, and with a mouse-click leads to a more comprehensive description of the geohazard represented by that polygon.

\section{1: Re-assessment of PanGeo data}

For this study, 52 Ground Stability shapefiles and corresponding Geohazard Descriptions were downloaded from the PanGeo website and merged into a single database, yielding 1286 geohazard 'records' in total (a database record can relate to one polygon of one geohazard type, or to $>1$ polygon of the same geohazard type, a multipart polygon). Values for the 'area' database field were missing for 248 of the records, requiring a re-computation of the associated polygons, which was carried out using the QGIS geographical information system.

A geohazard can exist within, or overlap, another geohazard (e.g. a landslide zone within an earthquake zone), and so the Ground Stability Layers could include overlapping polygons of different geohazard types, thus combining the hazard effects in that area. For that reason, the overall area of a city exposed to geohazards, referred to here as the 'geohazard footprint', was usually smaller than a simple addition of all individual polygons. Because it was necessary to know the overall area of each city exposed to geohazards, any overlapping polygons of different geohazard type were merged. 
The percentage of each urban area exposed to geohazards relied on knowing the area analysed for each city. The PanGeo Production Manual specifies that the EC 'Larger Urban Zone' (LUZ) definition should form the limit of analysis for each city (Roberts, 2015). However, examination of the Ground Stability Layers in QGIS revealed that varying criteria had been used: for some the LUZ boundary was used, for others a smaller municipal boundary, and for others the extent of the InSAR analysis was deemed sufficient. Careful reading of the Geohazard Description documents was needed to ensure that the correct size area was used, and in some cases a new polygon of analysis-extent was digitised from the information given.

Estimates of population exposure were made using Eurostat's 2011 GeoStat population grid (European Commission, 2016b). This is a grid of points at $1 \mathrm{~km}$ spacing with a population record for each point based on census data. As many smaller geohazard polygons would fall between the population points, the GeoStat points were merged in QGIS with a $1 \mathrm{~km}^{2}$ polygon grid, each cell taking the mean of the four points at each corner. Each Ground Stability Layer was then merged with the population grid, and where intersections occurred, the population summed. This resulted in some over-estimates because geohazard polygons might only partially intersect population cells, but the results were indicative and systematically biased over the entire analysis. For reasons unknown, the 2011 GeoStat data did not include values for Cyprus or Luxembourg, therefore the estimates of population for the towns of Lefkosia and Luxembourg were calculated using regression analysis and ranking against other European cities, given a geohazard of specific type and area. Statistical work was done using IBM's Statistical Package for the Social Sciences (SPSS).

There were two further anomalies: the London Ground Stability Layer shapefile had been made by only polygonising areas of ground motion from the InSAR result. Polygons representing London Clay, responsible for damaging shrink-swell cycles (BGS Geohazards Team, 2012) were missing. Furthermore, $350 \mathrm{~km}^{2}$ of ground motion depicted in the InSAR result which could be associated with shrink-swell clays, were classified as 'unknown'. A new polygon was therefore made by digitising around the London Clays depicted on a 1:50,000-scale London geology map available from www.geofacets.com. The new polygon was bounded by the overall area analysed and classified as 'geological potential'. It was then integrated into the existing London Ground Stability shapefile, and where it intersected with existing polygons of 'unknown' class, that part of the latter was deleted. 
Another anomaly involved the 'Earthquake' geohazard type. After an initial analysis of the data, it was decided to omit this geohazard type and its five corresponding records from the study for four reasons:

- The inclusion of polygons relating to earthquake hazard had been rather arbitrary with, for instance, no seismic-hazard threshold defined.

- Some geological surveys had not been clear on whether to include earthquake hazard polygons as they would cover the entire area of analysis.

- The five existing 'Earthquake' records accounted for $34 \%$ (over $6000 \mathrm{~km}^{2}$ ) of the total geohazard coverage, thereby having a significant impact on the analysis although the coverage was judged inaccurate.

- Limiting the area of earthquake hazard to the area analysed could be confusing and dangerous to those considering earthquake risk.

A complete database was then assembled, containing 1281 records of 18 geohazard-types for 52 cities, each record giving: geohazard group, geohazard type, determination method, confidence level, observation date, area, and population. These data were further analysed using SPSS and MS Excel to produce a series of statistics and charts, discussed below.

\section{3: RESULTS}

Global statistics for all 52 cities are presented first. This is followed by detail of the frequency and probability of geohazards, before looking at geohazards by city, and then by type. The total population for all 52 cities covered by the analysis was 75,000,000, approximately $15 \%$ of the EU27 population (at the time of the PanGeo project, there were $27 \mathrm{EU}$ countries). The average area analysed per city was $996 \mathrm{~km}^{2}$. The total area analysed within the 52 cities was $51,800 \mathrm{~km}^{2}$, of which nearly $10,000 \mathrm{~km}^{2}$ (20\%) was deemed hazardous, with nearly 32.5 million people exposed. The summed area of individual geohazard polygons was $18.5 \%$ larger than the 'geohazard footprint', due to geohazards of one type overlapping geohazards of another. 


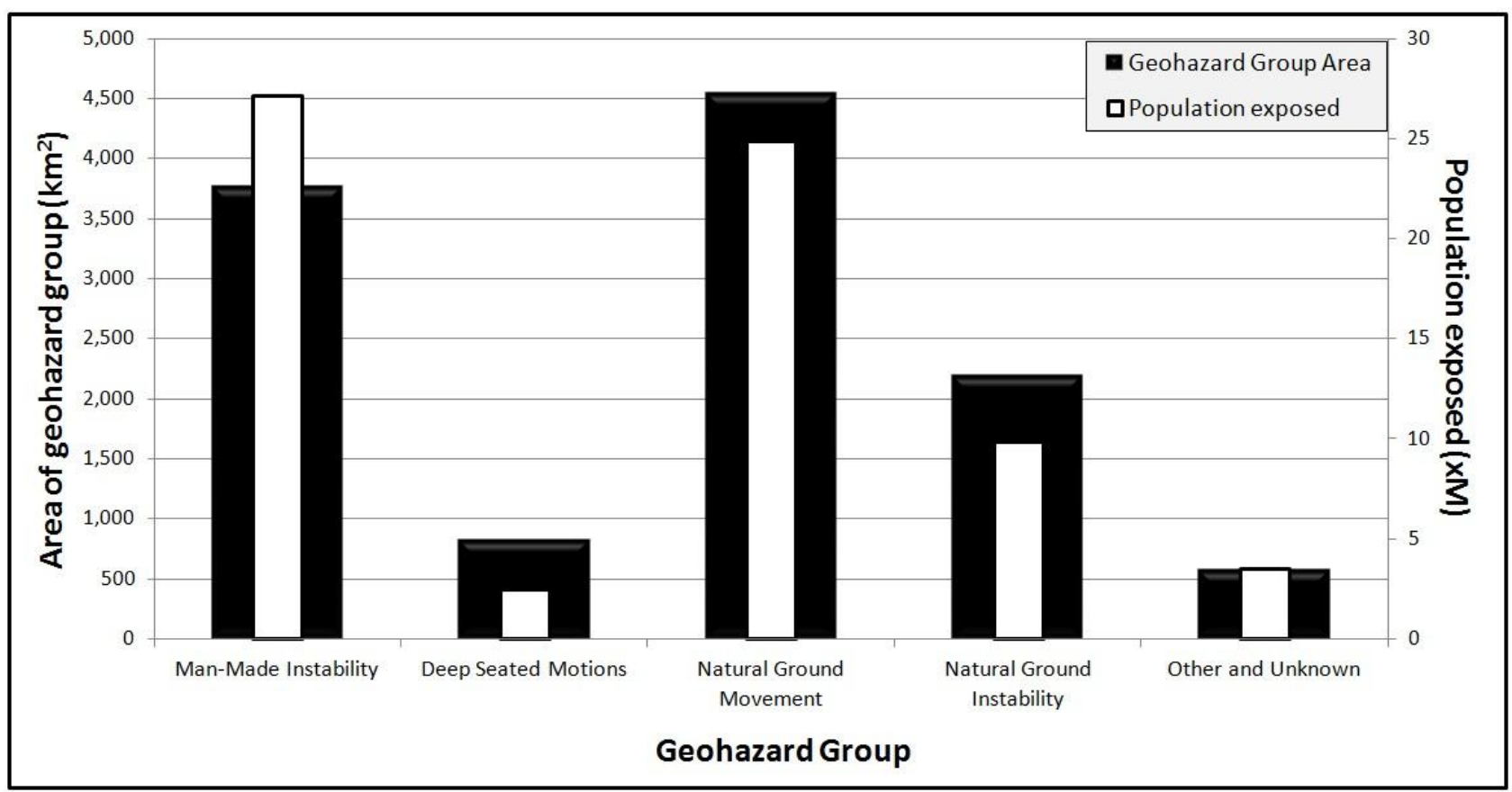

Figure 4: Areas $\left(\mathrm{km}^{2}\right)$ of geohazard group vs population exposed. Populations for each geohazard group cannot be added as many geohazard types overlap.

In Figure 4, the total area of each of the geohazard groups is shown, compared to the populations exposed (the 'other \& unknown' categories are combined). The 3,760 km² of 'Man-Made Instability' had a large population exposure, ca. 27 million, suggesting that anthropogenic intervention, such as construction, positively correlates with population density. Almost 25 million people were exposed to 'Natural Ground Movement' which covers an area of $4,538 \mathrm{~km}^{2}$ and includes the 'shrink-swell clays' geohazard. Due to some large areas of geohazard, only $10 \%$ of the 1281 geohazard records account for $95 \%$ of the total geohazard area. 


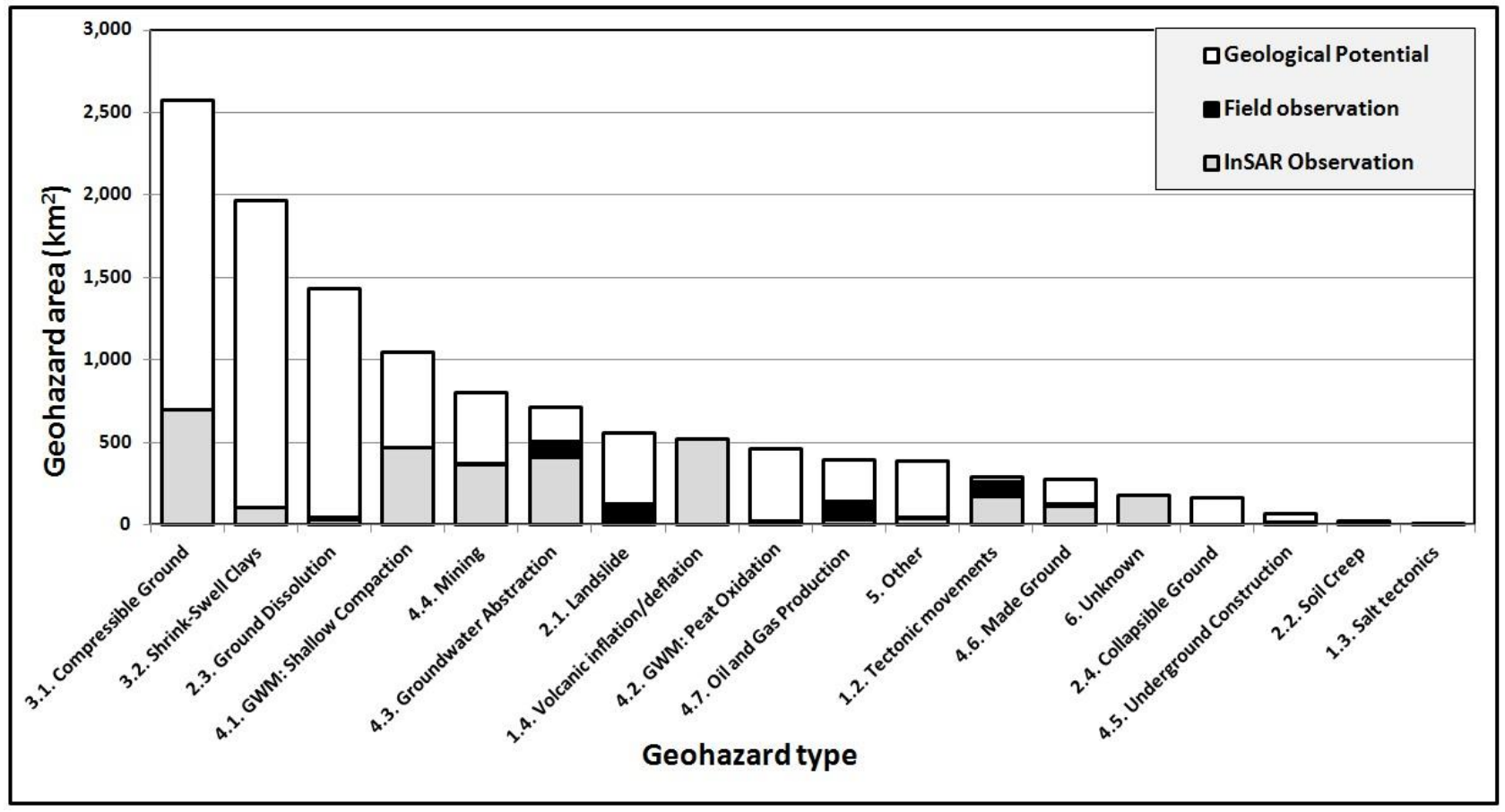

Figure 5: Area $\left(\mathrm{km}^{2}\right)$ of geohazard types by method of determination

Three methods were used for geohazard determination: (i) interpretation from InSAR, (ii) observation in the field, or (iii) mapping as 'potential' geohazards from geology maps (Figure 5). The 'geological potential' method accounted for only $21 \%$ of all geohazard records, but, due to the nature of drawing polygons around areas of common geology, the method accounted for nearly $69 \%$ of the total area of geohazards mapped. Conversely, $21 \%$ of records were 'observed in the field' yet it represented only $4 \%$ of total geohazard area $\left(480 \mathrm{~km}^{2}\right)$, perhaps unsurprising, considering the limited ability of field observers to cover much ground. All polygons classified as 'unknown' were interpreted from InSAR. The analysis indicates the substantial contribution of InSAR, especially for the mapping of 'compressible-ground', 'compaction', 'mining' and 'waterabstraction'. Nearly $60 \%$ of all records ( $27 \%$ of total geohazard coverage) were derived from satellite InSAR: the inference being that those instances of geohazard would otherwise have gone undetected, at least until some adverse geohazard effect was observed. InSAR is seen to offer a proactive solution for urban geohazard detection, informing emergency planners and potentially enhancing disaster risk reduction efforts.

An analysis was made to assess the relationship between the size of the areas analysed and the size of geohazard footprints, and also to determine the probability of geohazard occurrence. Figure 6 shows a scatter-plot of the area analysed in relation to the area of geohazard footprint. Two clusters of cities appear present in the plot; a group of six cities with geohazard areas $>400$ 
$\mathrm{km}^{2}$ (London, Rome, Faro, Amsterdam, Rotterdam and Toulouse), and another of the remaining 46 cities with geohazard areas $<400 \mathrm{~km}^{2}$. Lines of linear regression were put through these two clusters, as well as for all 52 cities.

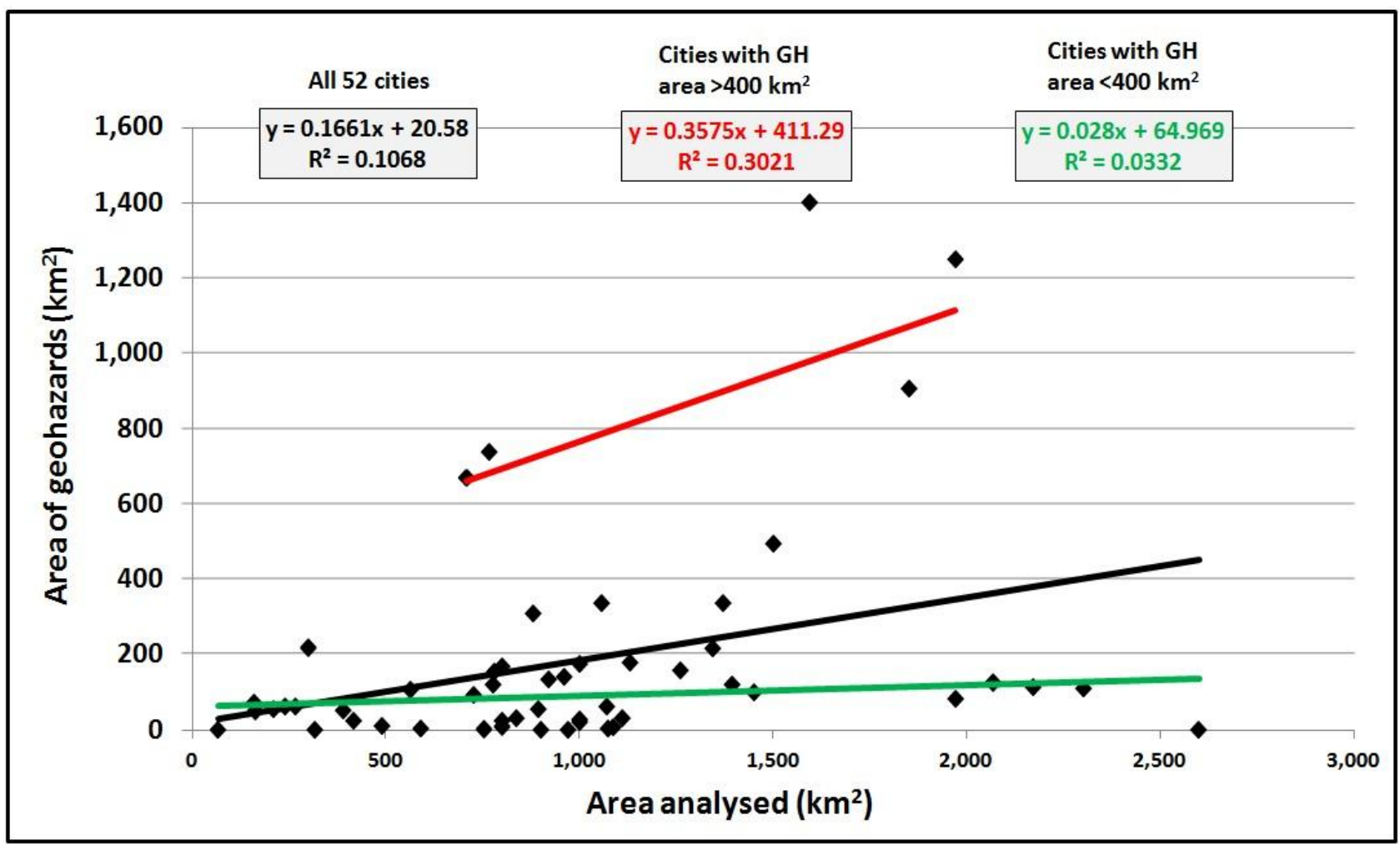

Figure 6: Relationship between area analysed and area of geohazards

When considering all 52 cities, the relationship between the area analysed and area of geohazard was weak with a coefficient of determination $\left(R^{2}\right)$, giving an indication of the fit of the linear regression, of only 0.1 , indicating that $89 \%$ of the variation in the size of geohazard footprint is not due to the size of the area analysed, but is unexplained (the main driver probably being the underlying geology). On the basis of this weak correlation, the predicted area of geohazard footprint in the sampled European cities was the area analysed multiplied by $0.17+21$.

The regression through the six cities with geohazard areas $>400 \mathrm{~km}^{2}$, showed a stronger relationship with an $\mathrm{R}^{2}$ of 0.3 . These cities lie in the top $17 \%$ of all 52 cities when ranked by the percentage of the area analysed being geohazardous (see Figure $9 a$ ), all having $>30 \%$ geohazard coverage. There appears no geohazard-correlation between these six cites, with the main drivers as follows: London - shrink-swell clays, Amsterdam - peat oxidation, Rotterdam - peat oxidation 
and gas, Faro - ground dissolution, Toulouse - shrink-swell clays, Rome - volcano, compressible and collapsible ground, landslides.

With the six outliers excluded, regression through the remaining 46 cities showed little correlation with an $\mathrm{R}^{2}$ of 0.03 (97\% of variation in geohazard area not due to area analysed). With large-area potential earthquakes areas excluded, this result maybe as expected, with the area of a city exposed to geohazards not determined by how large that city is but rather by its underlying geology.

The average area of each city exposed to geohazards was $19 \%$ of the area analysed. However, the data were positively skewed (1.8) and a boxplot analysis showed a $50 \%$ quartile range from $2 \%$ $18 \%$ of geohazard coverage, with a median of $7 \%$. The plot treated as outliers the same six cities clustered in the scatterplot with geohazard areas $>400 \mathrm{~km}^{2}$ (Figure 7).

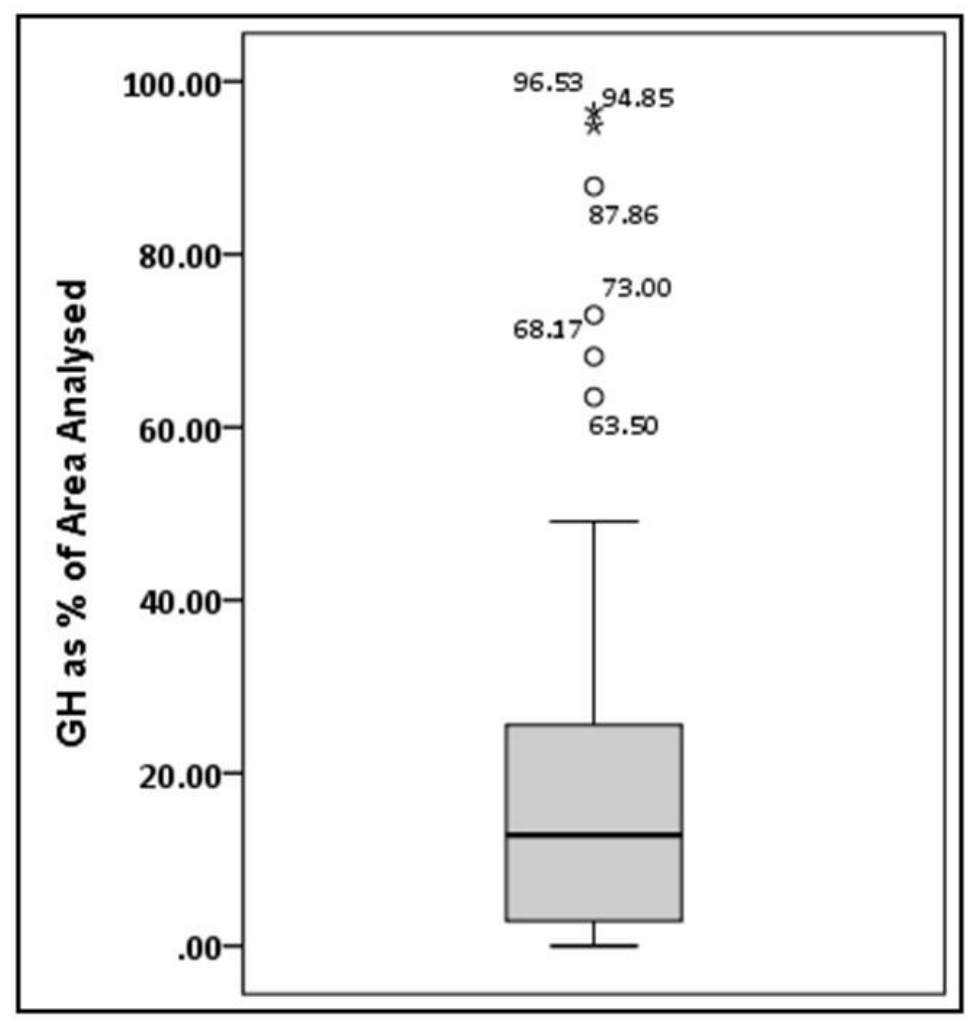

Figure 7: Boxplot of geohazard (GH) area as percentage of area analysed 


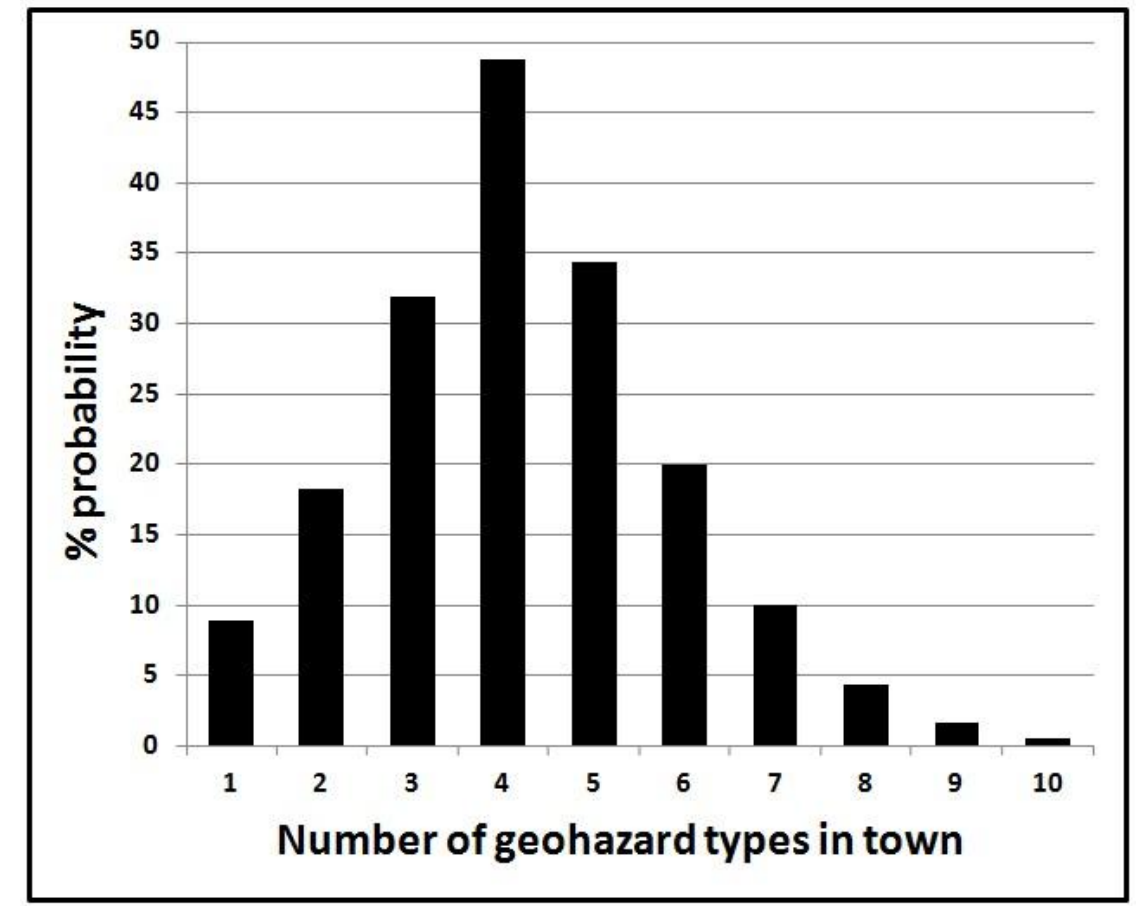

Figure 8: Probability distribution for geohazard occurrence

Figure 8 shows the probability distribution for geohazard-type occurrence per city. In other words, from the 52 cities analysed, what was the chance of a city having $x$ number of the 18 geohazard types? The chart shows how every city had at least one type of geohazard, and that a city had a $49 \%$ chance of having four geohazard types. The average number of geohazard types per city was $4.17(\sigma=2.3)$. The inference here, given this sample of 52 cities, is that all large European cities are exposed to geohazards of some description - the issues are widespread.

The data analysed suggests that an average city of 1.5 million people could have 4 different types of geohazard covering an area of $186 \mathrm{~km}^{2}(\sigma=298)$, exposing 626,000 people. The four most likely types of geohazard are 'man-made-ground', 'compressible-ground', 'landslide' and 'other', i.e. mapped from InSAR but with the cause not known.

The next three results consider the data by city. Figure 9a shows all 52 cities ranked by the amount of their area that was exposed to geohazards. Amsterdam and Rotterdam were both ca. 95\% exposed, due mainly to peat oxidation and compressible ground in the former, and gas production and shallow compaction in the latter. London was $88 \%$ exposed to 8 different hazard types, including large areas of shrink-swell clays. 
Figure $9 \mathrm{~b}$ shows the area of geohazards for each city compared to the population exposed, providing a population density indicator. It reveals how London had by far the most exposure with $8.2 \mathrm{M}$ people residing within geohazardous areas covering $1,400 \mathrm{~km}^{2}$. Rome had the next largest geohazard footprint $\left(1,250 \mathrm{~km}^{2}\right)$, but only $3 \mathrm{M}$ people exposed. Overall, Malta was the most stable, with the least exposure to geohazards.

Figure 9c shows the number of different geohazard types in a city compared to the area analysed. There appears no correlation between the amount of area analysed and the number geohazard types present in the 52 cities analysed. Indeed, Palermo in Italy had the second smallest area analysed $\left(159 \mathrm{~km}^{2}\right)$, yet 10 different types of geohazard - equal only with Vienna that had the $10^{\text {th }}$ smallest area analysed $\left(415 \mathrm{~km}^{2}\right)$. Conversely, Hannover in Germany had only three geohazards mapped, yet $2,600 \mathrm{~km}^{2}$ were analysed. 


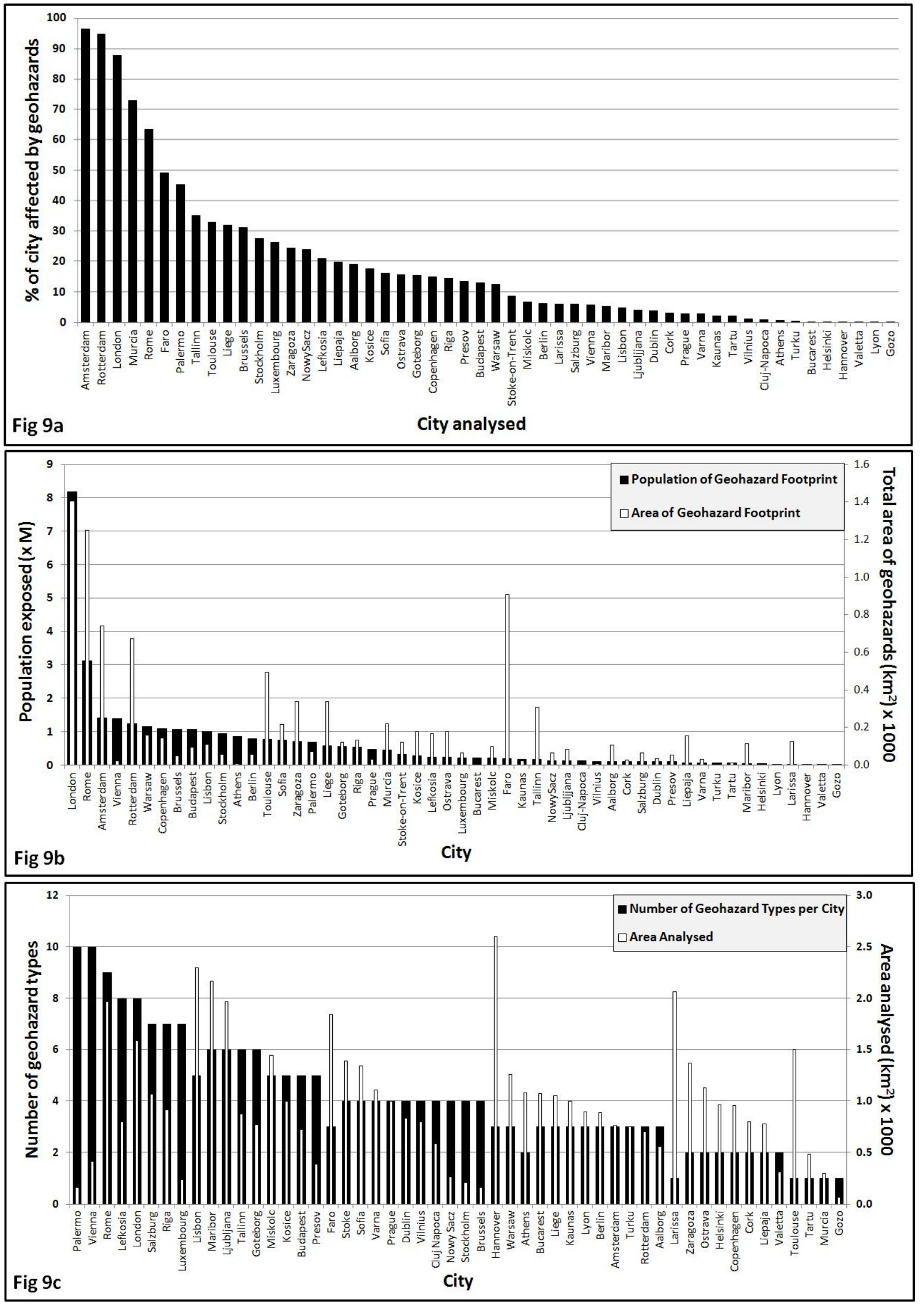

Figure 9a: Cities ranked by geohazard footprint as \% of area analysed. Figure 9b: Population exposed vs geohazard area $\left(\mathrm{km}^{2}\right)$, by city. Figure 9c: Number of geohazard types per city vs the area analysed. $G H=$ geohazard. 
The final set of results consider the PanGeo data by geohazard type. Figure 10a shows the percentage of cities exposed to geohazards by type, compared to the total area of that geohazard type. For example, looking at the first two columns from the left, over $60 \%$ of all cities were exposed to geohazards from 'made-ground' and 'compressible-ground', although the combined area of the latter exceeded that of the former by 9:1. The percentages on the left vertical axis can be viewed as the probability of the geohazard-type occurring, e.g. the study suggests there was a $56 \%$ chance that landslides would affect any individual European city. The data revealed that issues relating to 'salt tectonics' in this sample were minimal with only one geohazard record relating to $4 \mathrm{~km}^{2}$ exposing 25,000 people. Figure 10b charts the area of each geohazard type, compared to the number of people exposed. In the 52 cities sampled, over 16 million people were exposed to the possible effects of compressible-ground. There were also large exposures to 'shrink-swell clays' (ca. 8.8 million) and 'made-ground' (ca. 8.5 million). Population estimates for each geohazard type should not be added, because polygons of different geohazard types could overlap. Figure 10c shows the total area of each geohazard type, compared with its number of records. 'Compressible-ground' represented the largest geohazard by area $\left(2,570 \mathrm{~km}^{2}\right)$, and had the largest number of records $(313-24 \%)$, perhaps unsurprising considering that most European cities have evolved near rivers and/or coasts, where compressible sediments and alluvium often accumulate. There were also many records for 'landslide' (292), 'made-ground' (169), 'mining' (122) and 'soil creep' (97). Those geohazard types constituted 77\% of all records, but only $36 \%$ of total geohazard area, suggesting these geohazard types were of smaller area but higher frequency as illustrated in Figure 11. 


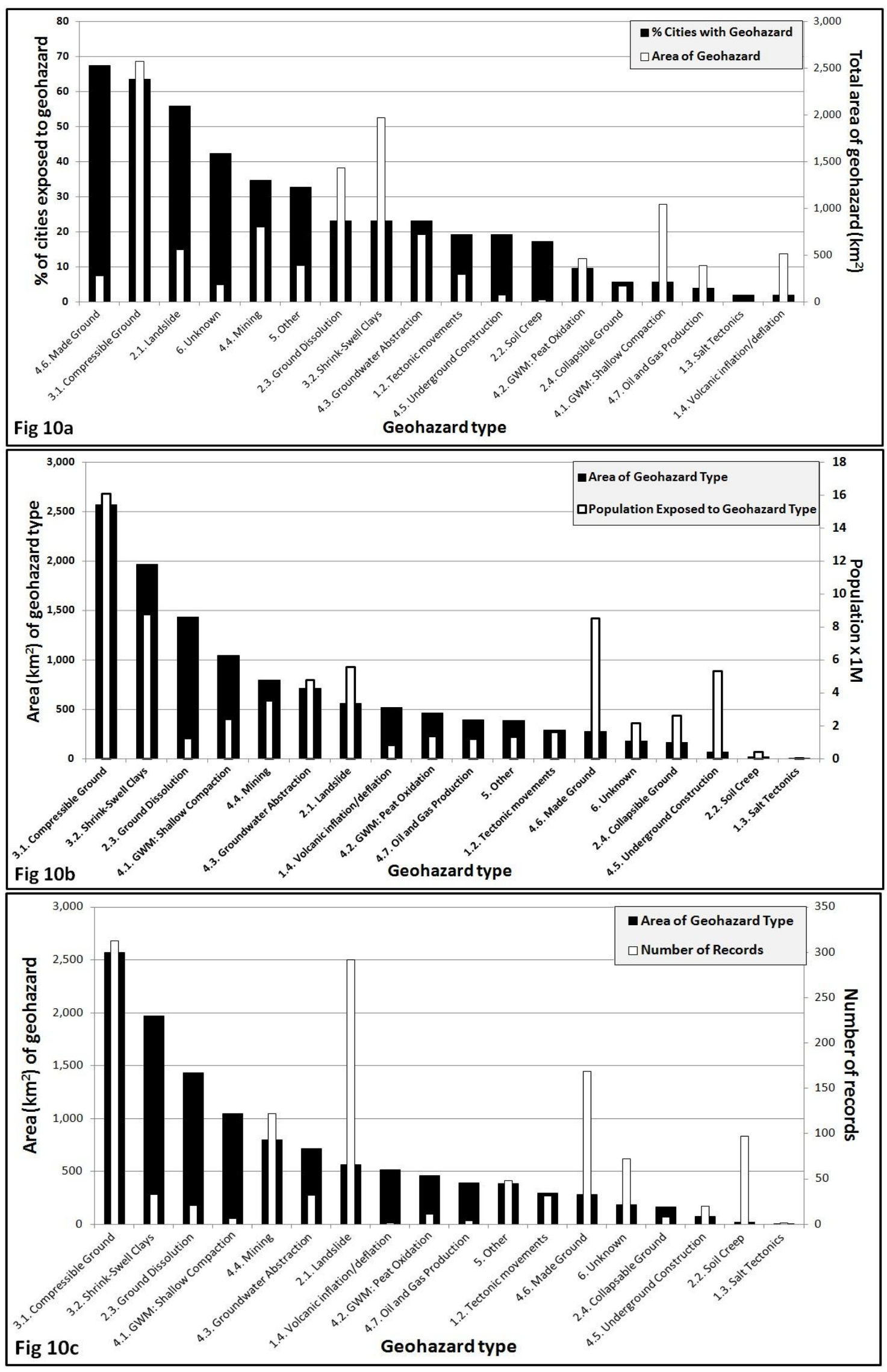

Figure 10a: Percentage of cities exposed to geohazards vs geohazard area $\left(\mathrm{km}^{2}\right)$. Figure 10b: Area $\left(\mathrm{km}^{2}\right)$ of geohazard type vs population exposed. Figure 10c: Geohazard type by area $\left(\mathrm{km}^{2}\right)$ vs number of records. 
The final chart, Figure 11, shows the number of records by geohazard-type compared to the average area of record. A high number of records with low mean area indicates many small instances of a given geohazard. The results show that 'compressible ground' had 313 records with an average area of $8.2 \mathrm{~km}^{2}$ illustrating the hazard's widespread ubiquity and probable correlation with urban development. Other similarly ubiquitous geohazards were those associated with landslides, made ground, mining and soil-creep. Meanwhile, the one volcano record for Rome had an area of $518 \mathrm{~km}^{2}$, reflecting the wide-area nature of this geohazard-type

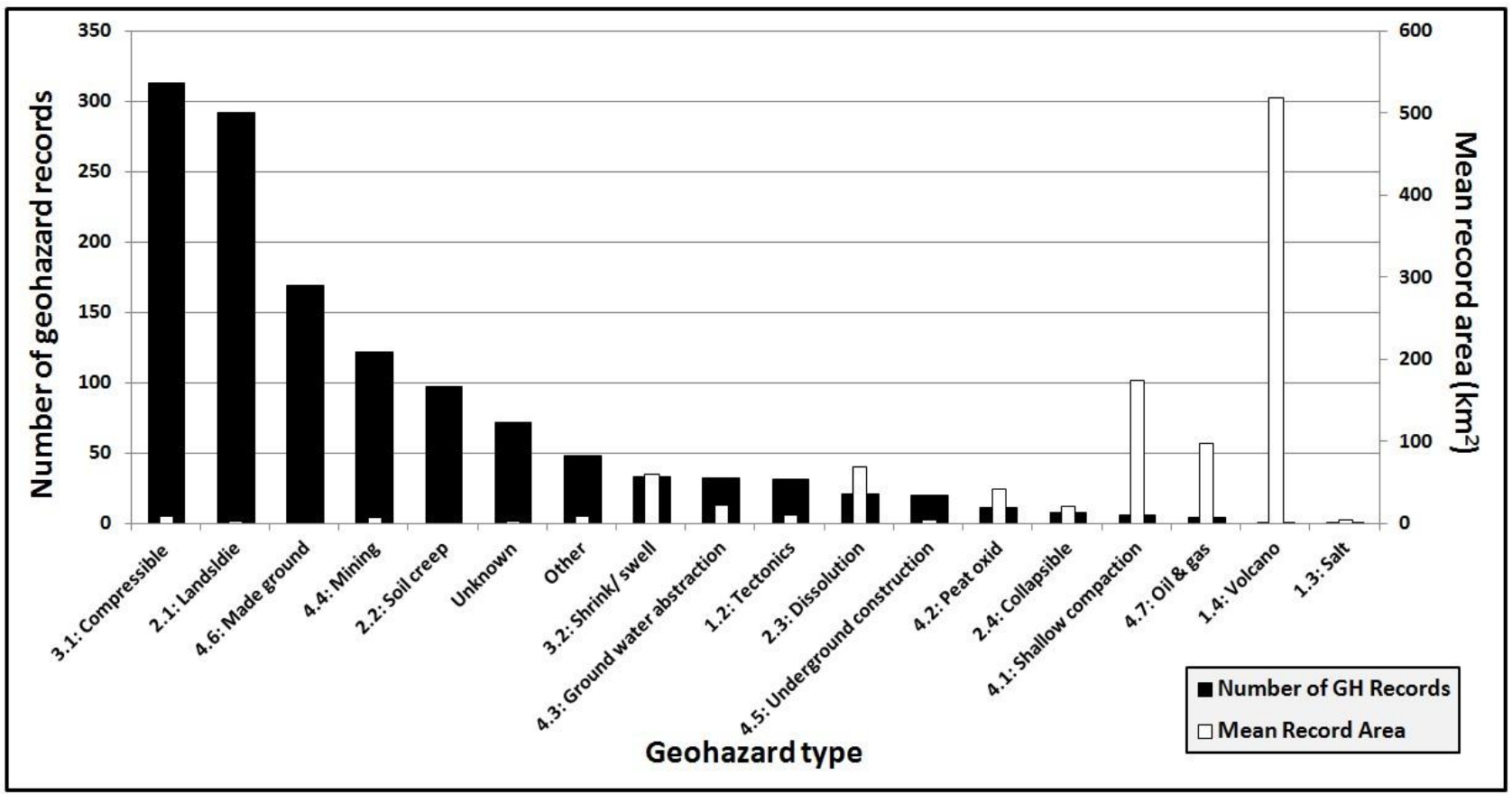

Figure 11: Number of geohazard records vs mean record area

\section{4: DISCUSSION}

With the costs of shrink-swell clays in the UK amounting to a quarter of a billion Euros a year over the last 40 years (MunichRe, 2016) the costs to society of all the geohazards involved, mapped across urban areas of Europe, are open to further research. A conspicuous feature of this analysis was the ubiquity of geohazards in European cities - a fifth (19\%) of all urban area, and nearly half (43\%) its population, are exposed to at least one form of geohazard. These statistics indicate the need for routine and standardised information on European geohazards: current systems, when they exist at all, tend to under-sample the insidious and slow-moving geohazards that can damage infrastructure and buildings, and usually focus on life-threatening geohazards only. 
The fact that the majority of geohazard records (60\%) were derived from InSAR is a remarkable achievement for Earth observation. Even more so, considering the R\&D nature of the European Space Agency missions involved (ERS-1/2, 1991- 2011, Envisat, 2002-2012), with both satellite SAR sensors only providing 35-day sampling rates (repeat imaging), and with many, often conflicting, scientific objectives that disrupted the consistent flow of InSAR-compliant data. This situation has now radically changed, with the EU's Copernicus Programme (www.copernicus.eu) and the Sentinel-1 satellite mission, which aims to provide high-quality InSAR services on a reliable and routine basis. The higher sampling rate and spatial resolution of these satellites means that their data products have better 'deformation resolution' and are better able to handle a wider range of ground motion velocity. For example, the UK NERC-funded project 'Looking Into the Continents from Space' will InSAR-map the world's earthquake belts with a deformation-rate resolution of just $1 \mathrm{~mm} /$ year over $100 \mathrm{~km}$ (Wright, 2016). As sensitivity improves and new processing algorithms are developed, more of what was currently mapped as a potential geohazard from the interpretation of a geological map, might in future be mapped as 'observed by InSAR' from more direct observation. If the PanGeo project were repeated using Sentinel-1 data (given the same temporal extent of archive), it is suggested the overall number of geohazard records would increase, as would the proportion determined from InSAR interpretation. That being so, it is still the case that some forms and rates of terrain motion will not be detected by InSAR due to issues of poor coherence, signal aliasing with larger magnitude displacements, and non-linear motions.

\section{1: Limitations of the study}

The aim of PanGeo was to productise InSAR for the good of local authorities, the public and others. It was not designed as an experiment to assess geohazard distribution across large European cities in general, hence the inclusion of cities with known or suspected geohazards that may have biased the analyses. However, the datasets assembled were created according to a systematic methodology, and they warranted a collective analysis, particularly to be of interest to European policy-makers. It is suggested that, although there may be some bias, the results are indicative of the nature and distribution of geohazards across large European cities.

The Ground Stability Layers were made by 27 different national geological surveys, of varying size and capability. Extracting results of a consistent and standardised nature would have been a challenge. To that end comprehensive documentation was provided, including a production manual, a product specification, and a dossier of quality assurance aimed at users (Roberts, 2015). 
The impressive results of the national geological surveys' work has enabled a systematic analysis of the geohazards across 52 European cities. However, there is still room for improvement in quality control and policy, given that some polygons were overlooked or omitted, and there was confusion on the interpretation of earthquake geohazards.

Population estimates should be considered as indicative only, because some significant overestimates of exposure are presumed. This is due to the comparatively coarse resolution of the population database ( $1 \mathrm{~km}^{2}$ grid) compared to geohazard polygon areas: 968 of the 1286 polygons were smaller than $1 \mathrm{~km}^{2}$, although the average area was $14 \mathrm{~km}^{2}$. The over-estimation could not be usefully quantified because it was dependent on the polygon size and shape, the population cell's value, and the amount of overlap at each population cell. Over-estimates would lessen as the size of polygons increase, and the proportion of partial cell-cover decreases. It would be preferable to improve the spatial resolution of the population grid, for instance, to $100 \mathrm{~m}^{2}(10 \mathrm{~m} \mathrm{x}$ $10 \mathrm{~m}$ ) cell size.

\section{2: Further research}

This study could provide stimulation for further analysis of the same data, or the application of the data-gathering exercise to other cities. There are, after all, a further 253 cities in the EU with $>100,000$ people, as well as important non-urban infrastructure (such as power plants, dams, bridges, canals and utility 'life lines'), all susceptible to geohazards. As well as attempting to provide a continued or expanded public service, further work could include a more controlled choice of targets, enabling a more experimentally-valid approach to a statistical assessment of geohazard distribution across Europe. An ongoing service with routine updates (now made possible with free Sentinel-1 SAR data) would help assess the time-dependency of some geohazards.

A key unanswered question concerns the costs caused by urban geohazards, due to damage and disruption. No attempt has been made in this study to map the costs of the geohazards: the effort involved would be substantial and worthy of a further research project. Cost estimates are obtainable for, e.g., losses due to earthquakes, and for some shrink-swell clays. However, translating into costs the areas and people exposed to geohazards when unknown parameters include the numbers or types of affected structure, and the average cost of repair, requires 
considerably more work, probably involving both an insurer with access to claims history and a civil engineer with an understanding of remediation costs.

Analysis with other datasets besides population could be useful, and correlation with land cover types could provide further data on exposure and vulnerability. A useful example, could be the EC-funded Urban Atlas, available via the European Environment Agency website (European Environment Agency, 2016). This provides 1:10,000 scale, 20-class land cover maps (derived from $2.5 \mathrm{~m}$ optical satellite imagery) for the $305 \mathrm{EU}$ cities with populations greater than 100,000. A limitation of the data is the bundling together of industrial, commercial, military, public and private land cover types into one class. Varying urban fabric densities are however differentiated, along with communications.

For interpretation by the geological surveys, the InSAR data were visualised as a 2D map indicating average annual ground velocity in the satellite line of sight. This is made by making a linear regression through each scatterer's time-series to calculate an average annual displacement. Doing this has the effect of averaging-out noise, but also, significantly, discounts ground deformations occurring in a non-linear fashion, e.g. clay shrink-swell cycles. It is therefore likely that some ground instabilities present in the period represented by the InSAR processing epochs were not detected by the technique. There is also the issue of the time-dependency and lifecycles of various geohazards, e.g. the average annual velocity map implicitly averages out any instantaneous, one-off displacement that may have occurred. However, as stated, the InSAR data represented just one source of information to the expert interpreter, and so, in the example of clay shrink-swells, the presence of certain surficial clays is enough to interpret a potential geohazard.

The InSAR data contain the time-series of ground deformation for each measurement point, as determined by the system's sampling rate, i.e. the satellite's 35-day repeat imaging (for both ERS and Envisat) of the same locations in the same imaging geometry. Different time-series display different profile characteristics, dependent on the nature of the ground motion involved. For instance subsidence from mining might display much steeper time-series than those measuring the settlement in compressible-ground (Colesanti, Ferretti, Prati, \& Rocca, 2003). The introduction of polynomial modelling in time-series generation, allowing for changing rates of motion, could expand this characterisation further (Ferretti, Bianchi, Prati, \& Rocca, 2005; Ferretti, Prati, \& 
Rocca, 2000). With the amount of data generated in the PanGeo project, it would be useful to analyse for correlations between InSAR time-series profiles and geohazard-type. This could help in determining the nature of some 'unknowns'. This would, however, require access to the InSAR results, which are not publicly available. Work on characterising geohazards by time-series profile would be assisted by the potential 6-day sampling rate from Sentinel-1a and $1 \mathrm{~b}$ combined.

The geohazard polygons were awarded one of four confidence levels - high, medium, low, and 'external' when evidence for the hazard came from elsewhere. Analysis shows that confidence levels were high for a third of all records determined by InSAR, for half of records determined from geological maps, and for $65 \%$ of records determined through field observation. It would be interesting to investigate correlations between geohazard types, methods of determination and confidence levels, to see if InSAR is particularly suited to the detection of any particular geohazard type.

\section{5: CONCLUSION}

This work presents a first systematic synopsis of urban geohazards based on a sample of 52 European cities. A collective area representing $15 \%$ of the EU population was analysed, nearly half of which was shown to be exposed to at least one type of geohazard. The average city, with 1.5 million people, could have 4 types of geohazard covering an area of $186 \mathrm{~km}^{2}$, exposing 626,000 people. On average, $20 \%(\sigma=25 \%)$ of each city area was exposed to at least one geohazard. The data was, however, positively skewed (1.8) and the median value was $13 \%$ with outliers included. More people were exposed to geohazards in London than the other 51 cities, although Amsterdam and Rotterdam had the highest proportion of their areas (ca. 95\%) exposed to one or more geohazards.

The most common geohazard was 'made-ground' followed by 'compressible-ground', perhaps indicative of population increase and the frequent association of urban areas with riparian and/or coastal zones. There was no correlation between the size of area analysed and the number of geohazard types present. For instance, Palermo, the second smallest area analysed, is exposed to 10 geohazard-types. Only a weak correlation was shown between the size of the area analysed and the extent of geohazard, with $89 \%$ of the variability related to other factors, such as the difference in underlying geology from one city to another. 
In this study, 60\% of the 1281 geohazard records were interpreted from satellite radar interferometry, the inference being that without this technology, these hazards would have gone un-noticed until some adverse and possibly costly consequence was observed. Satellite radar interferometry has proved to be a valuable tool in the detection and mapping of urban geohazard phenomena, and the new EU-funded Sentinel-1 mission, dedicated to providing routine and operational InSAR services, can only enhance this value. Geohazards are costly and ubiquitous: this study highlights the need for further research and the establishment of publicly-funded, routine, satellite InSAR-based mapping and monitoring of urban geohazards.

\section{ACKNOWLEDGEMENTS}

Thanks go to the European Commission, the European Space Agency, and to the 37 participants of the FP7 PanGeo project (EC project 262371), namely; the British Geological Survey (UK), Landmark Information Group (UK), Nederlandse Organisatie voor Toegepast Natuurwetenschappelijk Onderzoek (NL), Systèmes d'Information à Référence Spatiale (FR), Consorci Institut de Geomàtica (ES), Bureau de Recherches Géologiques et Minières (FR), EuroGeoSurveys (BE), European Federation of Geologists (BE), AB Consulting (UK), TRE (IT), Altamira Information (ES), Gamma Remote Sensing (CH), Geologische Bundesanstalt (AT), Institut Royal des Sciences Naturellesde Belgique (BE), University of Mining \& Geology (BG), Ministry of Agriculture, Natural Resources and Environment (CY), Ceska Geologicka Sluzba (CZ), Geological Survey of Denmark and Greenland (DK), Eesti Geoloogiakeskus OÜ (EE), Geologian tutkimuskeskus (FI), Bundesanstalt für Geowissenschaften und Rohstoffe (DE), Ethniko Kentro Viosimis Kai Aeiforou Anaptyxis (GR), Magyar Földtani és Geofizikai Intézet (HU), Department of Communications, Energy and Natural Resources (IE), Istituto Superiore per la Protezione e la Ricerca Ambientale (IT), Latvijas Universitate (LV), Lietuvos geologijos tarnyba prie Aplinkos ministerijos (LT), Service géologique du Luxembourg (LU), Malta Resources Authority (MT), Panstwowy Instytut Geologiczny (PL), Laboratório Nacional de Energia e Geologia, I. P. (PT), Institutul Geologic al Romaniei (RO), Statny Geologicky Ustav Dionyza Stura (SK), Geološkega zavoda Slovenije (SI), Instituto Geológico y Minero de España (ES), Sveriges Geologiska Undersokning (SE) and NPA Satellite Mapping (UK).

\section{REFERENCES}

BGS Geohazards Team. (2012). Ground shrinking and swelling. UK Geohazard Note, May 2012. Natural Environment Research Council. pp1-4. Retrieved from www.bgs.ac.uk/downloads/start.cfm?id=2499

Booth, K., Diaz Doce, D., Harrison, M., \& Wildman, G. (2010). User Guide for the British Geological Survey GeoSure dataset. Open Report OR/14/012. Natural Environment Research Council. 
Capes, R. Marsh, S. (Ed). (2009). Terrafirma User Guide: A guide to the use and understanding of Persistent Scatterer Interferometry. European Space Agency, (Special Publication).

Colesanti, C., Ferretti, A., Prati, C., \& Rocca, F. (2003). Monitoring landslides and tectonic motions with the Permanent Scatterers Technique. Engineering Geology, 68(1-2), 3-14. http://doi.org/10.1016/S0013-7952(02)00195-3

Crosetto, M., Monserrat, O., Bremmer, C., Hanssen, R., Capes, R., \& Marsh, S. (2008). Ground motion monitoring using SAR interferometry: Quality assessment. European Geologist Magazine, No. 26, pp12-15.

Crosetto, M., Monserrat, O., Cuevas-González, M., Devanthéry, N., \& Crippa, B. (2015). Persistent Scatterer Interferometry: A review. ISPRS Journal of Photogrammetry and Remote Sensing. http://doi.org/10.1016/j.isprsjprs.2015.10.011

European Commission. (2016a). Land cover, land use and landscape - Statistics Explained. European Commission. GeoStat pages. European Commission. Retrieved from http://ec.europa.eu/eurostat/statisticsexplained/index.php/Land_cover,_land_use_and_landscape\#tand_cover

European Commission. (2016b). Population grids - Statistics Explained. EuroStat pages. Retrieved June 1, 2016, from http://ec.europa.eu/eurostat/statisticsexplained/index.php/Population_grids

European Environment Agency. (2010). Mapping the impacts of natural hazards and technological accidents in Europe. An overview of the last decade. Technical report No 132010. European Environment Agency, Copenhagen. http://doi.org/10.2800/62638

European Environment Agency. (2016). Urban Atlas. European Environment Agency. Retrieved June 6, 2016, from http://www.eea.europa.eu/data-and-maps/data/urban-atlas

Ferretti, A., Bianchi, M., Prati, C., \& Rocca, F. (2005). Higher-order permanent scatterers analysis. Eurasip Journal on Applied Signal Processing, 2005(20), 3231-3242. http://doi.org/10.1155/ASP.2005.3231

Ferretti, A., Prati, C., \& Rocca, F. (2000). Nonlinear subsidence rate estimation using permanent scatterers in differential SAR interferometry. IEEE Transactions on Geoscience and Remote Sensing, 38(5 I), 2202-2212. http://doi.org/10.1109/36.868878

Ferretti, A., Prati, C., \& Rocca, F. (2001). Permanent Scatters in SAR Interferometry. IEEE Transactions on Geoscience and Remote Sensing, 39(1), 8-20. http://doi.org/10.1109/36.898661

Gabriel, A. K., Goldstein, R. M., \& Zebker, H. A. (1989). Mapping small elevation changes over large areas: Differential radar interferometry. Journal of Geophysical Research: Solid Earth, 94(B7), 9183-9191. http://doi.org/10.1029/JB094iB07p09183

Howard, A. (1999). Urban Geohazards: A European Perspective. British Geological Survey: Earthwise. Official Magazine of the British Geological Survey. Issue 14, p23, British Geologial Survey.

Kaluarachchi, Y., Indirli, M., Ranguelov, B., \& Romagnoli, F. (2014). The ANDROID Case Study; Venice and its Territory: Existing Mitigation Options and Challenges for the Future. In Procedia Economics and Finance, 4th International Conference on Building Resilience, 2014, Salford Quays, UK. (Vol. 18, pp. 825-836). http://doi.org/10.1016/S2212-5671(14)01007-7

Massonnet, D., Rossi, M., Carmona, C., Adragna, F., Peltzer, G., Feigl, K., \& Rabaute, T. (1993). The displacement field of the Landers earthquake mapped by radar interferometry. Nature, 364(6433), 138-142. http://doi.org/10.1038/364138a0

McCann, T. (Ed). (2008). The Geology of Central Europe, Vol 1. (T. McCann, Ed.). The Geological Society of London.

Ministry of Defence. (2014). Global Strategic Trends - Out to 2045 (5th ed.). Ministry of Defence. Crown Copyright. Retrieved from 
https://www.gov.uk/government/uploads/system/uploads/attachment_data/file/348164/20 140821_DCDC_GST_5_Web_Secured.pdf

MunichRe. (2016). Geophysical Hazards. MunichRe online magazine "Touch". Retrieved November 10, 2016, from

https://www.munichre.com/touch/naturalhazards/en/naturalhazards/geophysicalhazards/index.html

Roberts, C. (2015). PanGeo Final Report Summary. European Commission - CORDIS. Retrieved October 18, 2016, from http://cordis.europa.eu/result/rcn/156084_en.html

UNISDR. (2016). UNISDR International Strategy for Disaster Reduction (ISDR), Basic terms of disaster risk reduction. Retrieved May 31, 2016, from http://www.unisdr.org/we/inform/terminology\#letter-g

Wright, T. J. (2016). The earthquake deformation cycle. Astronomy \& Geophysics, 57(4), 4.20-4.26. http://doi.org/10.1093/astrogeo/atw148

6247 words 